\title{
PREFACE TO THE 1957 EDITION
}

It seems that I no longer need to worry about the first roar of indignation-the first confrontation of Trans-Atlantyk with the reader happened a couple of years ago, in exile, and is behind me. It is therefore time to avert another danger, namely that of the work being read in a manner that is too narrow and too shallow.

I must insist that today, on the eve of its publication in Poland, the text be given a deeper and more comprehensive reading. I must insist on this-because in some measure this work concerns our nation, while our mentality, in exile as well as within our country, is not yet free-minded enough on this matter, it continues to be fitful and even pretentious ... We do not know how to read books on this subject in a simple way. Our Polish complex is thus far too intense, and we are too much burdened by tradition. Some people (I used to be one of them) are almost afraid of the word "fatherland," as if it takes their development thirty years back. It takes others immediately onto the path of the compulsory stereotypes in our literature. Am I exaggerating? Yet the mail brings me various voices about TransAtlantyk, and I learn that it is "a pamphlet on the god-fatherland platitude" or "a satire on prewar Poland" ... Someone even 
qualified it as ... a pamphlet on sanacja." On this scale of things the best opinion I could hope for would be one that sees in this work a "national self-examination," as well as a "criticism of our national flaws."

But why do I need do battle with a deceased, prewar Poland or with the outworn style of the old patriotism when I have other, more universal quandaries? Why would I want to waste time on timeworn trivia? I am one of those ambitious shooters who, if they botch things up, it's because they take on bigger beasts.

I do not deny: Trans-Atlantyk is, among other things, a satire. It is also, among other things, a rather intense reckoning ... but, obviously, not with the Poland of our time, but with the Poland that has been created by her historical existence and her location in the world (this means a $\mathrm{w}$ e a $\mathrm{k}$ Poland). And I concur that Trans-Atlantyk is a corsair ship that smuggles a lot of dynamite in order to explode our hitherto-felt national emotions. It even conceals within it a requirement of sorts with regard to certain emotions: to overcome Polishness. To loosen up our submission to Poland! To break away just a little! Rise from our knees! To reveal, legalize another dimension of feeling which orders a human being to defend himself against his nation as against any collective force. To obtain-this is most importantfreedom from the Polish form, while being a Pole to be some-

*Józef Piłsudski’s political system after 1926. 
one larger and higher than a Pole! Here it is-Trans-Atlantyk's ideological contraband. This might mean a very far-reaching revision of our relationship to the nation-so far-reaching that it might totally transform our frame of mind and liberate energies that would, as the final outcome, be useful to the nation. A revision, nota bene, of a universal character-I might propose this to peoples of other nations, because the problem is not only the relationship of a Pole to Poland but that of any human being to his nation. And finally a revision as it most closely relates to all the contemporary problems, because I have my sights (as always) on strengthening, enriching the life of the individual, making him more resistant to the oppressive superiority of the masses. This is the ideological mode in which Trans-Atlantyk is written.

I have written many times about these ideas in my diary published in the Paris Kultura. The Diary has now appeared as a book, in Paris. The excerpt from the Kultura of March 1957 that makes also a commentary on my heresy did not appear in that book.

However, is the above idea the subject of my book? Is art supposed to be an essay on a subject? These questions are probably timely because, I'm afraid, the critics in Poland have not yet recovered from the mania of social realism that demands "art on a subject." No, Trans-Atlantyk does not have a subject beyond the story that it is telling. It is just a tale, nothing more than just a narrative of a certain world-that can only be worth something 
as long as it turns out to be funny, colorful, exploratory and evocative-it is something shining, shimmering, glimmering with a multitude of meanings. Trans-Atlantyk is, in bits and pieces, all you might want: a satire, a criticism, a treatise, fun, absurdity, a drama-but it is not exclusive of anything because it is only me, my "vibration," my catharsis, my existence.

Is this about Poland? I don't feel entitled to write about her-I have never written a single word about anything except about me. In the year 1939 I found myself in Buenos Aires, cast out of Poland and out of my former life, in an extremely dangerous situation. A bankrupt past. The present like the night. My future inscrutable. No support from anywhere. The Form is breaking up and falling apart under the blows of universal Becoming ... What's old is nothing but impotence, what's new and incoming is violence. In this wasteland of anarchy, among toppled gods, I am left to my own devices. What do you want me to feel at such a moment? To destroy the past within me? . . . To surrender to the future? . . . Yes . . . but I didn't want to surrender my very person to anything, to any incoming configuration-I wanted to be something higher and richer than a configuration. Hence the $1 \mathrm{a} u \mathrm{~g}$ h t e r in Trans-Atlantyk. Such was, more or less, my adventure that generated a grotesque book, spread-eagled between the past and the future.

To make things clear one must add, perhaps unnecessarily: Trans-Atlantyk is a fantasy. Everything-is invented with only a 
very loose connection to the real Argentina and to the Polish colony in Buenos Aires. My "defection" also proves to be different in reality (I refer searchers to my diary).

Witold Gombrowicz 
This page intentionally left blank 
Trans-Atlantyk 
This page intentionally left blank 